\title{
Venous thromboembolism in critically ill COVID-19 patients receiving prophylactic or therapeutic anticoagulation: a systematic review and meta-analysis
}

\author{
Syed Shahzad Hasan ${ }^{1}$ - Sam Radford ${ }^{2,3} \cdot$ Chia Siang Kow ${ }^{4} \cdot$ Syed Tabish Razi Zaidi ${ }^{5,6}$
}

Published online: 3 August 2020

(c) The Author(s) 2020

\begin{abstract}
Many aspects of care such as management of hypercoagulable state in COVID-19 patients, especially those admitted to intensive care units is challenging in the rapidly evolving pandemic of novel coronavirus disease 2019 (COVID-19). We seek to systematically review the available evidence regarding the anticoagulation approach to prevent venous thromboembolism (VTE) among COVID-19 patients admitted to intensive care units. Electronic databases were searched for studies reporting venous thromboembolic events in patients admitted to the intensive care unit receiving any type of anticoagulation (prophylactic or therapeutic). The pooled prevalence (and 95\% confidence interval [CI]) of VTE among patients receiving anticoagulant were calculated using the random-effects model. Subgroup pooled analyses were performed with studies reported prophylactic anticoagulation alone and with studies reported mixed prophylactic and therapeutic anticoagulation. We included twelve studies (8 Europe; 2 UK; 1 each from the US and China) in our systematic review and meta-analysis. All studies utilized LMWH or unfractionated heparin as their pharmacologic thromboprophylaxis, either prophylactic doses or therapeutic doses. Seven studies reported on the proportion of patients with the previous history of VTE (range 0-10\%). The pooled prevalence of VTE among ICU patients receiving prophylactic or therapeutic anticoagulation across all studies was 31\% (95\% CI 20-43\%). Subgroup pooled analysis limited to studies reported prophylactic anticoagulation alone and mixed (therapeutic and prophylactic anticoagulation) reported pooled prevalences of VTE of 38\% (95\% CI 10-70\%) and 27\% (95\% CI 17-40\%) respectively. With a high prevalence of thromboprophylaxis failure among COVID-19 patients admitted to intensive care units, individualised rather than protocolised VTE thromboprophylaxis would appear prudent at interim.
\end{abstract}

Keywords Anticoagulation · Coronavirus 2019 · COVID-19 · Critically ill · Venous thromboembolism

\section{Highlights}

Electronic supplementary material The online version of this article (https://doi.org/10.1007/s11239-020-02235-z) contains supplementary material, which is available to authorized users.

Syed Shahzad Hasan

s.hasan@hud.ac.uk

1 School of Applied Sciences, University of Huddersfield, Huddersfield, UK

2 Intensive Care Unit, Austin Health, Melbourne, Australia

3 School of Medicine, University of Melbourne, Melbourne, Australia

4 School of Postgraduate Studies, International Medical University, Kuala Lumpur, Malaysia

5 School of Healthcare, University of Leeds, Leeds, UK

6 Leeds Teaching Hospitals Trust, Leeds, UK
- Despite receiving anticoagulation for thromboprophylaxis, a high rate of venous thromboembolism was still observed among COVID-19 patients admitted to the intensive care unit.

- The failure rate of pharmacological thromboprophylaxis may be lower with the use of therapeutic anticoagulation among COVID-19 patients admitted to the intensive care unit.

- An individualized dosing approach of anticoagulant based on anti-factor Xa monitoring, thromboelastography, or rotational thromboelastometry may be useful to reduce the rate of venous thromboembolism COVID-19 patients. 


\section{Introduction}

The novel coronavirus disease 2019 (COVID-19) has claimed over 500,000 lives and infected well over 9 million people as of 27th June 2020 [1]. COVID-19 infection has demonstrated a range of phenotypes from asymptomatic, all the way to multiorgan failure and death. Among the COVID19 population admitted to intensive care units (ICUs) there has been considerable reporting of venous thromboembolism (VTE). Though hypercoagulability in COVID-19 has been well-recognized, uncertainty still exists as to how best to manage clotting risk in these patients. Like many aspects of care in this rapidly evolving pandemic, the evidence is scarce with adequate quality to inform the approach to the hypercoagulable state in COVID-19 patients.

Since the recognition of the hypercoagulable state in COVID-19 patients, several interim guidance documents have recommended the use of pharmacologic thromboprophylaxis in hospitalized patients with COVID-19 [2-4]. Most of these guidelines [2-4] recommend the use of unfractionated heparin (UFH) or low molecular weight heparin (LMWH), though the consensus is yet to reach in the recommendations of prophylactic, intermediate, or therapeutic (full) dose anticoagulation. Nevertheless, it is not fully understood how effective pharmacologic thromboprophylaxis in preventing VTE among COVID-19 critically ill patients. We seek to systematically review the available evidence to help guide clinicians weighing up decisions regarding the anticoagulation approach for COVID-19 patients admitted to intensive care units.

\section{Methods}

This systematic review with meta-analysis was conducted with adherence to the Preferred Reporting Items for Systematic Reviews and Meta-analyses (PRISMA) guidelines [5]. Two authors (CSK and SSH) independently performed a systematic literature search in PubMed, and Google Scholar and two preprint servers (medRxiv and SSRN) up to 25th June 2020. Search terms are depicted in Table S1. The titles and abstracts of the resulting articles were examined to exclude irrelevant studies. The full texts of the remaining articles were read to determine if these articles meet our eligibility criteria. Bibliographies of retrieved articles were also reviewed for additional studies. The studies eligible for inclusion reported on the prevalence of venous thromboembolic event (deep vein thrombosis and pulmonary embolism) in patients admitted to the intensive care unit (ICU) receiving any type of anticoagulation (prophylactic or therapeutic). Articles were excluded if they consist of no original data, report combined arterial and venous thromboembolic events, report mixed ICU and medical patients, or report no pharmacologic thromboprophylaxis. Case study, case series, and case report that may not reflect the true prevalence of VTE were also excluded.

Two authors (CSK and SSH) independently reviewed the primary studies to assess the appropriateness for inclusion and data were extracted. Any discrepancies were addressed by a joint re-evaluation of the original article. The information extracted from each study included the name of the first author, the country from which the study was reported, the design of the study, age information of patients, the proportion of patients with a reported previous history of VTE, information on body weight or body mass index, information on the anticoagulant regimen, and the proportion of patients who developed VTE.

The outcome measure was the prevalence of patients receiving anticoagulants who developed VTE from individual studies. The pooled prevalence (and 95\% confidence interval $[\mathrm{CI}]$ ) of VTE among patients receiving anticoagulant were calculated using the random-effects model. Subgroup pooled analyses were performed with studies reported prophylactic anticoagulation alone and with studies reported mixed prophylactic and therapeutic anticoagulation. All meta-analytical calculations were performed using Meta XL, version 5.3 (EpiGear International, Queensland, Australia) [6]. We examined the heterogeneity between studies using the $I^{2}$ statistics with $50 \%$ as the threshold for statistically significant heterogeneity.

\section{Results}

Our search yielded 1,056 titles from the selected databases (Fig. 1), of which 535 titles were duplicates. The remaining 521 records were screened as per PRISMA guidelines against the eligibility criteria described in the previous section. A total of 493 records were excluded after reading the title and abstract. The full-texts of the remaining 28 articles were retrieved for a detailed evaluation. Sixteen articles were excluded due to reasons including absence of original data, reported mixed intensive care units and medical patients, case study/series/report, reported combined arterial and venous thromboembolic events and reported no pharmacologic thromboprophylaxis.

We eventually identified twelve studies [7-18] that reported the prevalence of VTE among ICU patients receiving prophylactic or therapeutic anticoagulation: three studies from France [7-9], two studies each from the Netherlands [10, 11], Italy [12, 13], the United Kingdom [14, 15], and one study each from the United States [16], China [17], and Germany [18]. The information extracted from each study is presented in Table 1 . The number of patients admitted to intensive care units ranged widely from 20 to 184 . Eight 
Fig. 1 Study selection process (PRISMA)
1,056 records identified through database searching:

PUBMED ( $n=524)$, Google Scholar $(n=405)$ \& medRxiv $(n=101)$, SSRN $(n=26)$

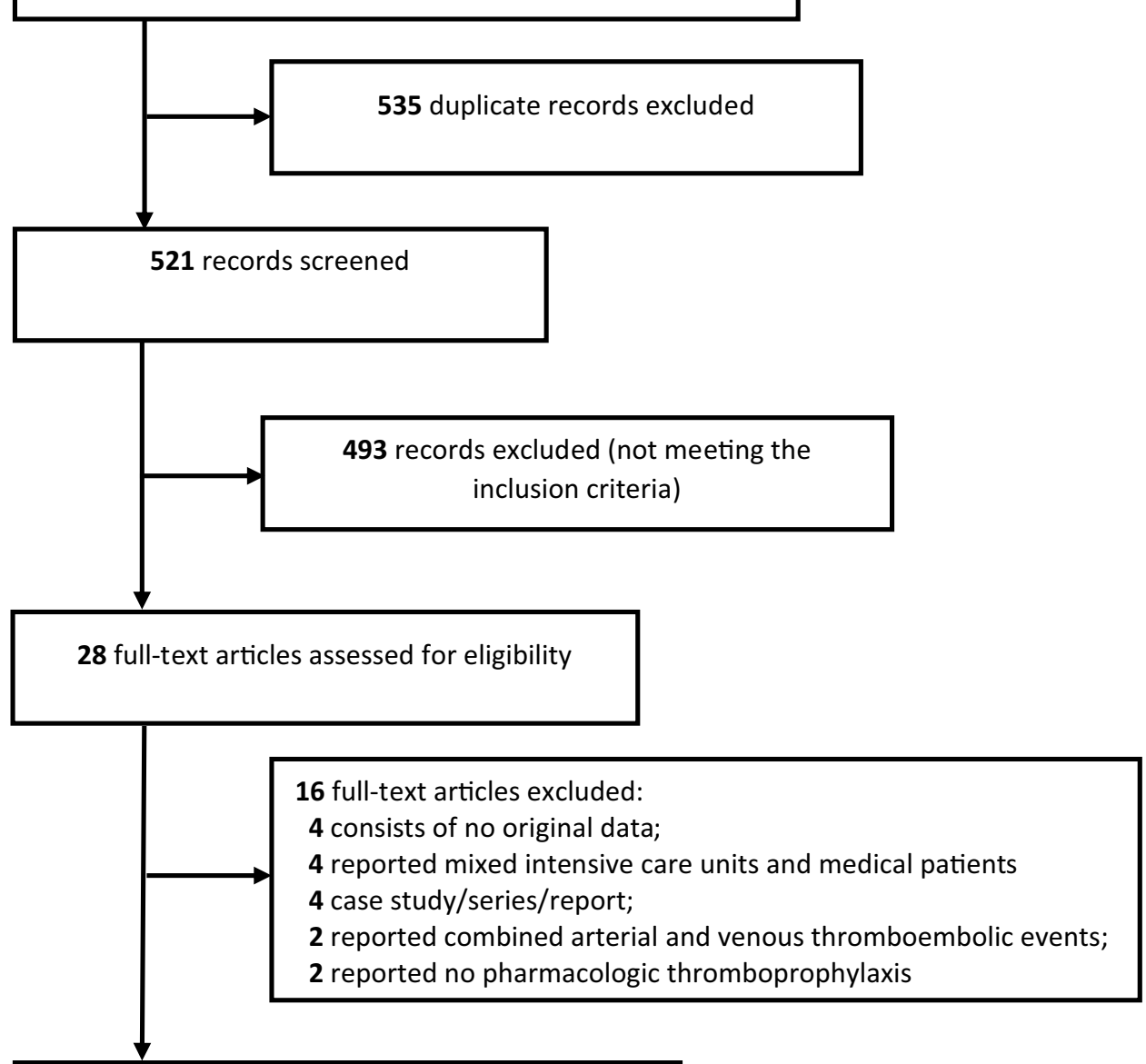

12 articles included in quantitative synthesis out of eleven studies used a retrospective chart review as their study design [7, 9-16], whereas among the remaining three studies, two reported prospectively enrolled cohort $[8$, 18] and one reported a cross-sectional analysis [17]. The mean/median age of patients ranged from 59 to 70 years old. Though not all studies reported on the proportion of patients with the previous history of VTE, we observed a low proportion $(0-5.3 \%)$ in studies $[7-10,12,14]$ which reported the figures except the study by Zerwes et al. [18] which reported a proportion of $10.0 \%$. All studies [7-18] utilized LMWH or unfractionated heparin as their pharmacologic thromboprophylaxis approach, though with a mixed proportion of patients receiving either prophylactic doses or therapeutic doses.

The pooled prevalence of VTE among ICU patients receiving prophylactic or therapeutic anticoagulation across all studies was 31\% (95\% CI 20-43\%; I2: 92\%) (Fig. 2).
Subgroup pooled analysis limited to studies reported prophylactic anticoagulation alone in all patients included [14-17] reported a pooled prevalence of VTE of 38\% (95\% CI 10-70\%; I2: 96\%) (Supplementary Fig. S1). Subgroup pooled analysis limited to studies reported mixed therapeutic and prophylactic anticoagulation in all patients included $[7-13,18]$ reported a pooled prevalence of VTE of $27 \%$ (95\% CI 17-40\%; I2: 89\%) (Supplementary Fig. S2).

\section{Discussion}

The hypercoagulable state in COVID-19, which has been termed thrombo-inflammation or COVID-19-associated coagulopathy (CAC) by some experts, can be explained in terms of Virchow's triad: endothelial injury, stasis of blood 
Table 1 Summary of studies reporting on the proportion of VTE among COVID-19 patients in ICU receiving anticoagulation

\begin{tabular}{|c|c|c|c|c|c|c|c|}
\hline Study & Country & Study design & $\begin{array}{l}\text { Mean/ } \\
\text { median } \\
\text { age }(y)\end{array}$ & $\begin{array}{l}\text { Proportion of } \\
\text { patients with } \\
\text { previous VTE } \\
(\%)\end{array}$ & $\begin{array}{l}\text { Body weight/ } \\
\text { BMI }\end{array}$ & $\begin{array}{l}\text { Anticoagulant } \\
\text { regimen }\end{array}$ & $\begin{array}{l}\text { Proportion of } \\
\text { patients who } \\
\text { developed VTE } \\
(\mathrm{n} / \mathrm{N})\end{array}$ \\
\hline Llitjos et al. [7] & France & $\begin{array}{l}\text { Retrospective, } \\
\text { multicenter }\end{array}$ & 68 & 3.8 & No mention & $\begin{array}{l}\text { LMWH or UFH } \\
\text { Prophylactic } \\
\text { anticoagula- } \\
\text { tion: } 31.0 \% \\
\text { Therapeutic } \\
\text { anticoagula- } \\
\text { tion: } 69.0 \%\end{array}$ & $18 / 26 ; 69.2 \%$ \\
\hline Helms et al. [8] & France & $\begin{array}{l}\text { Prospective, } \\
\text { multicentre }\end{array}$ & $63^{1}$ & 5.3 & No mention & $\begin{array}{l}\text { LMWH or UFH } \\
\text { Prophylactic } \\
\text { anticoagula- } \\
\text { tion: } 70.0 \% \\
\text { Therapeutic } \\
\text { anticoagula- } \\
\text { tion: } 30.0 \%\end{array}$ & $27 / 150 ; 18.0 \%$ \\
\hline Fraissé et al. [9] & France & $\begin{array}{l}\text { Retrospective, } \\
\text { single-center }\end{array}$ & 61 & 5.4 & $\begin{array}{l}\text { Median BMI: } \\
30 \mathrm{~kg} / \mathrm{m}^{2}\end{array}$ & $\begin{array}{l}\text { No mention of } \\
\text { anticoagulant } \\
\text { Prophylactic } \\
\text { anticoagula- } \\
\text { tion: } 46.7 \% \\
\text { Therapeutic } \\
\text { anticoagula- } \\
\text { tion: } 53.3 \%\end{array}$ & $19 / 92 ; 20.6 \%$ \\
\hline $\begin{array}{l}\text { Middledorp et al. } \\
\text { [10] }\end{array}$ & Netherlands & $\begin{array}{l}\text { Retrospective, } \\
\text { single-center }\end{array}$ & 62 & 2.8 & $\begin{array}{l}\text { Median BMI: } \\
27 \mathrm{~kg} / \mathrm{m}^{2} ; 17 \% \\
\text { of patients } \\
\text { with body } \\
\text { weight } \geq 100 \mathrm{~kg}\end{array}$ & $\begin{array}{l}\text { LMWH } \\
\text { Both prophylac- } \\
\text { tic and thera- } \\
\text { peutic antico- } \\
\text { agulationwere } \\
\text { utilized though } \\
\text { no breakdown } \\
\text { on prophylactic } \\
\text { vs. therapeutic } \\
\text { anticoagulation } \\
\text { was provided }\end{array}$ & $35 / 75 ; 46.7 \%$ \\
\hline Klok et al. [11] & Netherlands & $\begin{array}{l}\text { Retrospective, } \\
\text { multicenter }\end{array}$ & 64 & No mention & $\begin{array}{l}\text { Mean body } \\
\text { weight: } 87 \mathrm{~kg}\end{array}$ & $\begin{array}{l}\text { LMWH } \\
\text { Prophylactic } \\
\text { anticoagula- } \\
\text { tion: } 90.8 \% \\
\text { Therapeutic } \\
\text { anticoagula- } \\
\text { tion: } 9.2 \%\end{array}$ & $28 / 184 ; 15.2 \%$ \\
\hline $\begin{array}{l}\text { Lodigiani et al. } \\
\text { [12] }\end{array}$ & Italy & $\begin{array}{l}\text { Retrospective, } \\
\text { single-center }\end{array}$ & 61 & 0 & $\begin{array}{l}22.9 \% \text { of } \\
\text { patients with } \\
\text { BMI } \geq 30 \mathrm{~kg} / \mathrm{m}^{2}\end{array}$ & $\begin{array}{l}\text { LMWH } \\
\text { Prophylactic } \\
\text { anticoagula- } \\
\text { tion: } 95.8 \% \\
\text { Therapeutic } \\
\text { anticoagula- } \\
\text { tion: } 4.2 \%\end{array}$ & $8 / 48 ; 16.7 \%$ \\
\hline $\begin{array}{l}\text { Spiezia et al. } \\
\text { [13] }\end{array}$ & Italy & $\begin{array}{l}\text { Retrospective, } \\
\text { single-center }\end{array}$ & 67 & No mention & $\begin{array}{l}\text { Mean BMI: } 30 \mathrm{~kg} / \\
\mathrm{m}^{2}\end{array}$ & $\begin{array}{l}\text { LMWH } \\
\text { No breakdown } \\
\text { on prophylactic } \\
\text { vs. therapeutic } \\
\text { anticoagulation } \\
\text { was provided }\end{array}$ & $5 / 22 ; 22.7 \%$ \\
\hline $\begin{array}{l}\text { Thomas et al. } \\
\text { [14] }\end{array}$ & United Kingdom & $\begin{array}{l}\text { Retrospective, } \\
\text { single-center }\end{array}$ & 59 & 1.6 & $\begin{array}{l}80.9 \% \text { of patients } \\
\text { with body } \\
\text { weight between } \\
50-99 \mathrm{~kg}\end{array}$ & $\begin{array}{l}\text { LMWH } \\
\text { Prophylactic } \\
\text { anticoagula- } \\
\text { tion: } 100.0 \%\end{array}$ & $17 / 62 ; 27.4 \%$ \\
\hline
\end{tabular}


Table 1 (continued)

\begin{tabular}{|c|c|c|c|c|c|c|c|}
\hline Study & Country & Study design & $\begin{array}{l}\text { Mean/ } \\
\text { median } \\
\text { age }(y)\end{array}$ & $\begin{array}{l}\text { Proportion of } \\
\text { patients with } \\
\text { previous VTE } \\
(\%)\end{array}$ & $\begin{array}{l}\text { Body weight/ } \\
\text { BMI }\end{array}$ & $\begin{array}{l}\text { Anticoagulant } \\
\text { regimen }\end{array}$ & $\begin{array}{l}\text { Proportion of } \\
\text { patients who } \\
\text { developed VTE } \\
(\mathrm{n} / \mathrm{N})\end{array}$ \\
\hline $\begin{array}{c}\text { Desborough } \\
\text { et al. [15] }\end{array}$ & United Kingdom & $\begin{array}{l}\text { Retrospective, } \\
\text { single-center }\end{array}$ & 59 & No mention & $\begin{array}{l}\text { Median BMI: } \\
28 \mathrm{~kg} / \mathrm{m}^{2}\end{array}$ & $\begin{array}{l}\text { LMWH } \\
\text { Prophylactic } \\
\text { anticoagula- } \\
\text { tion: } 100.0 \%\end{array}$ & $10 / 66 ; 15.2 \%$ \\
\hline $\begin{array}{l}\text { Maatman et al. } \\
\text { [16] }\end{array}$ & United States & $\begin{array}{l}\text { Retrospective, } \\
\text { multicenter }\end{array}$ & 61 & No mention & $\begin{array}{l}\text { Mean BMI: } \\
34.8 \mathrm{~kg} / \mathrm{m}^{2}\end{array}$ & $\begin{array}{l}\text { LMWH or UFH } \\
\text { Prophylactic } \\
\text { anticoagula- } \\
\text { tion: } 100.0 \%\end{array}$ & $29 / 107 ; 27.1 \%$ \\
\hline Ren et al. [17] & China & $\begin{array}{l}\text { Cross-sectional, } \\
\text { multicentre }\end{array}$ & 70 & No mention & $\begin{array}{l}33.3 \% \text { of } \\
\text { patients with } \\
\text { BMI } \geq 24 \mathrm{~kg} / \mathrm{m}^{2}\end{array}$ & $\begin{array}{l}\text { LMWH } \\
\text { Prophylactic } \\
\text { anticoagula- } \\
\text { tion: } 100.0 \%\end{array}$ & $41 / 47 ; 87.2 \%$ \\
\hline $\begin{array}{l}\text { Zerwes et al. } \\
\text { [18] }\end{array}$ & Germany & $\begin{array}{l}\text { Prospective, } \\
\text { single-centre }\end{array}$ & 64 & 10.0 & $\begin{array}{l}\text { Mean BMI: } \\
28.1 \mathrm{~kg} / \mathrm{m}^{2}\end{array}$ & $\begin{array}{l}\text { LMWH or UFH } \\
\text { Both prophylac- } \\
\text { tic and thera- } \\
\text { peutic antico- } \\
\text { agulationwere } \\
\text { utilized though } \\
\text { no breakdown } \\
\text { on prophylactic } \\
\text { vs. therapeutic } \\
\text { anticoagulation } \\
\text { was provided }\end{array}$ & $4 / 20 ; 20.0 \%$ \\
\hline
\end{tabular}

$B M I$ body mass index, $L M W H$ Low molecular weight heparin, $U F H$ unfractionated heparin, VTE venous thromboembolism

Fig. 2 Pooled VTE prevalence (\%) in COVID-19 patients admitted to ICU receiving anticoagulation

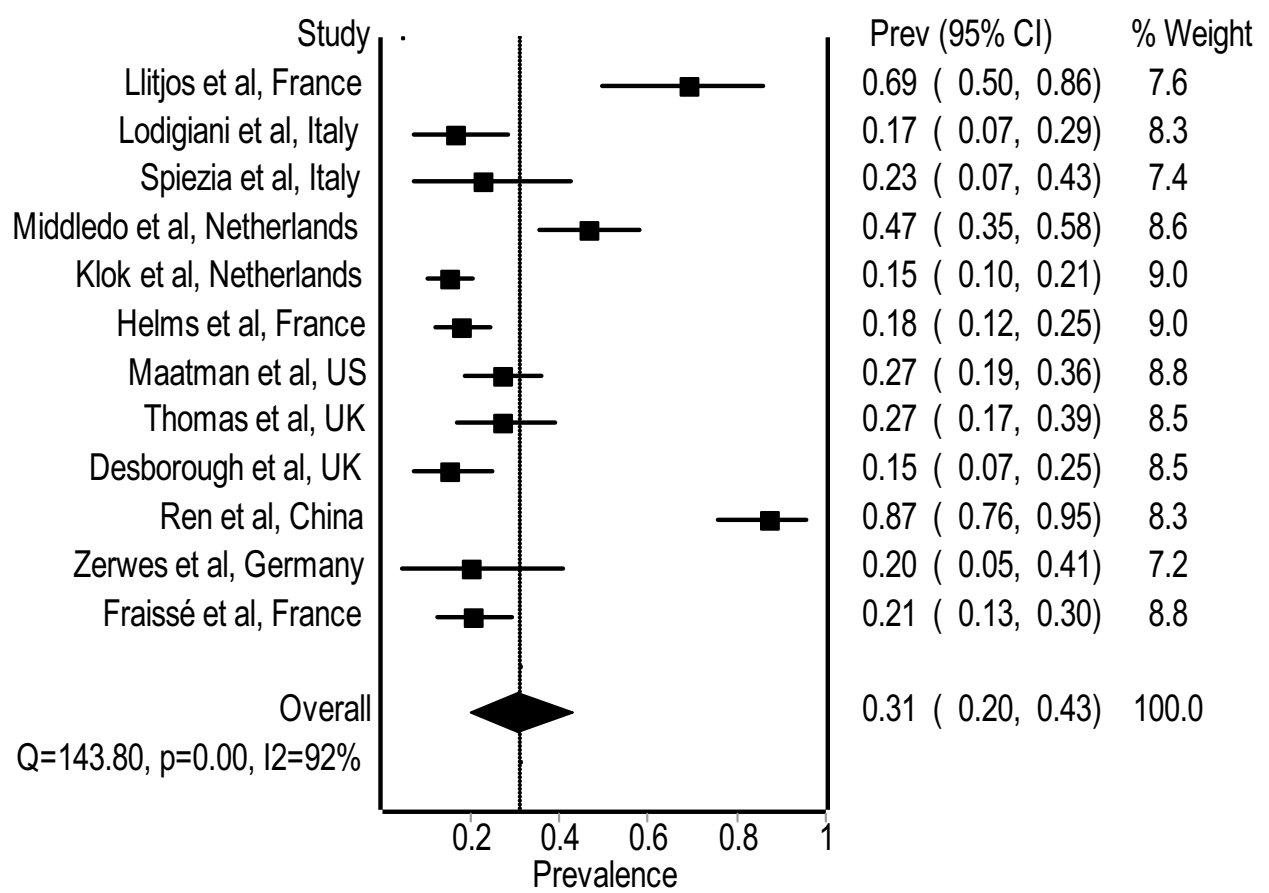


flow, and hypercoagulability. In terms of endothelial injury, there is evidence of direct invasion of endothelial cells by the SARS-CoV-2 virus, potentially leading to cell injury [19]. Other sources of endothelial injury may include intravascular catheters and mediators of the acute systemic inflammatory response such as cytokines (e.g., interleukin-6) other acute phase reactants [20]. On the other hand, immobilization during hospitalization with COVID-19, especially severely ill patients admitted to intensive care units, can cause stasis of blood flow. In terms of hypercoagulability, many changes in circulating prothrombotic factors have been reported or proposed in patients with severe COVID19, including elevated factor VIII level, elevated fibrinogen level, circulating prothrombotic microparticles, and neutrophil extracellular traps [21-23].

Therefore, with the recognition of hypercoagulability in COVID-19, the need for effective thromboprophylaxis cannot be overstated. Since no head-to-head trial comparing pharmacologic thromboprophylaxis versus no pharmacologic thromboprophylaxis among ICU patients, as of the time of writing (doubt such trial will be conducted), a comparison of our findings (Table 1) with non-COVID-19 critical care patients is worth exploring. The landmark PROphylaxis for ThromboEmbolism in Critical care (PROTECT) trial that compared the comparative effectiveness of LMWH and UFH in 3764 critically ill patients found the average incidence of VTE of $8.2 \%$ and $9.9 \%$, respectively [24]. A subsequent analysis of the PROTECT study by Lim et al. found an overall incidence of VTE of 7.7\% [25]. A more relevant comparison of our findings is with critically ill patients who developed sepsis during their hospitalisation, and thus may be at a higher risk of VTE prophylaxis failure. The incidence of VTE in sepsis patients admitted to ICU ranged from $12.5 \%$ in a retrospective study of 335 patients to $37 \%$ in a prospective study of 113 patients [26, 27]. it is important to note that in the aforementioned prospective study, the average body mass index (BMI) of included patients was $31.7 \mathrm{~kg} / \mathrm{m}^{2}$ and high BMI is a known factor of VTE as noted in the PROTECT sub-analysis [25].

Since preliminary evidence indicating a possibility of a higher rate of pharmacologic thromboprophylaxis failure in ICU patients with COVID-19 compared to their nonCOVID-19 counterparts, a reconsideration of the current approach may be needed, including the need to implement individualized VTE prophylaxis. It has previously been demonstrated that prophylactic LMWH dosing is associated with subtherapeutic anti-factor Xa levels in critically ill patients, and therefore an individualized dosing approach based on anti-factor Xa monitoring may be useful in COVID-19 patients [28-31]. Indeed, it has also been recently discovered that prophylactic LMWH dosing was associated with subtherapeutic anti-factor Xa levels among COVID-19 patients admitted to intensive care units. Dutt et al. [32] reported that
95\% of COVID-19 patients had sub-therapeutic anti-factor Xa levels despite prophylactic LMWH, a figure which was about 3.5 times higher compared to the patients admitted to medical wards $(27 \%)$.

The outcomes of individual adjustment of LMWH dosing guided by anti-factor Xa monitoring are encouraging, though thus far it was only investigated in surgical or trauma patients [33, 34]. The lower pooled prevalence of VTE in studies reported mixed anticoagulation approach (prophylactic and therapeutic) compared to studies reported prophylactic anticoagulation only (27\% versus $38 \%$ ) may have been possibly driven by on average higher rate of attaintment of target anti-factor Xa levels due to the use of therapeutic anticoagulation in some included patients. Nevertheless, subtherapeutic anti-factor Xa levels have also been observed in COVID-19 patients on twice-daily therapeutic LMWH regimens [35].

Similarly, anti-factor Xa monitoring in patients receiving unfractionated heparin is associated with better attainment of therapeutic anticoagulation compared to activated partial thromboplastin time monitoring whereby it shortens the time to reach the therapeutic range as well as improves the length of time in the therapeutic range [36]. In fact, the phenomenon of heparin resistance has been observed up to $80 \%$ of COVID-19 patients treated with unfractionated heparin in which there was a need for high doses of unfractionated heparin (more than 35,000 IU/day) to achieve the target activated partial thromboplastin time presumably due to increased factor VIII levels [37]. Patients requiring high doses of unfractionated heparin to achieve the target activated partial thromboplastin time may also develop lifethreatening bleeding events if they proceed without monitoring of antithrombotic activity via an anti-factor Xa assay.

There has been an increased interest to utilize thromboelastography (TEG) or rotational thromboelastometry (ROTEM) in critically ill COVID-19 patients where both tests may be useful to inform individualized clinical decision-making regarding VTE prophylaxis among COVID-19 patients [38]. Viscoelastic observations with TEG among critically ill COVID-19 patients in the intensive care unit revealed hypercoagulable state with decreased $\mathrm{R}$ time and $\mathrm{K}$ time as well as elevated fibrinogen activity greater than a $73^{\circ}$ angle and maximum amplitude more than $65 \mathrm{~mm}$ with heparinase correction $[39,40]$. Whereas, viscoelastic observations with ROTEM observed significantly higher maximum clot firmness and clotting time as well as significantly shorter clot formation time among COVID-19 patients compared with healthy controls $(\mathrm{p}<0.001)$ [41]. In fact, comparison among COVID-19 patients reported that maximum clot firmness and clotting time were significantly longer in those admitted to medical wards relative to those in specialized wards (intermediate wards/intensive care units). Thus far, there is only one randomized controlled trial [42] which 
assessed TEG-based protocol for the dosing of unfractionated heparin among patients receiving extracorporeal membrane oxygenation which reported reduced dose of heparin used compared with aPTT-based protocol, with no difference between the two protocols in terms of thrombotic and haemorrhagic events.

Our analysis does have some limitations. Firstly, there were no randomized controlled trials available that investigate the effectiveness of heparin-based pharmacological thromboprophylaxis among critically ill COVID-19 patients at the time of the literature search. Secondly, ten out of twelve studies included in our meta-analysis originate from European countries, which may limit the generalizability of the results to COVID-19 populations from other continents. Thirdly, we were unable to perform subgroup analysis strictly on patients receiving therapeutic anticoagulation and patients receiving prophylactic anticoagulation since the included original studies did not segregate their data based on the intensity of anticoagulation.

\section{Conclusions}

Further study into anticoagulant selection, dosing regimens, and monitoring are needed in this important population of critically ill COVID-19 patients admitted to intensive care units. Until prospective or randomised studies with a clear description of baseline factors and adequate follow up, the best approach for managing VTE will be uncertain. Individualised rather than protocolised thromboprophylaxis would appear prudent at interim. Besides, maintaining a strong index of suspicion for VTE and the possibility of chemoprophylaxis failure is recommended. Likewise, future studies may investigate the effectiveness of anti-factor Xa-guided or TEG/ROTEM-based heparin dosing in reducing the high prevalence of thromboprophylaxis failure in COVID-19 patients.

\section{Compliance with ethical standards}

Conflict of interest The authors declare that they have no conflict of interest.

Open Access This article is licensed under a Creative Commons Attribution 4.0 International License, which permits use, sharing, adaptation, distribution and reproduction in any medium or format, as long as you give appropriate credit to the original author(s) and the source, provide a link to the Creative Commons licence, and indicate if changes were made. The images or other third party material in this article are included in the article's Creative Commons licence, unless indicated otherwise in a credit line to the material. If material is not included in the article's Creative Commons licence and your intended use is not permitted by statutory regulation or exceeds the permitted use, you will need to obtain permission directly from the copyright holder. To view a copy of this licence, visit http://creativecommons.org/licenses/by/4.0/.

\section{References}

1. Dong E, Du H, Gardner L (2020) An interactive web-based dashboard to track COVID-19 in real time. Lancet Infect Dis. https:// coronavirus.jhu.edu/map.html. Accessed 27 June 2020

2. Zhai Z, Li C, Chen Y et al (2020) Prevention and treatment of venous thromboembolism associated with coronavirus disease 2019 infection: A Consensus Statement before Guidelines. Thromb Haemost 120(6):937-948

3. Bikdeli B, Madhavan MV, Jimenez D et al (2020) COVID-19 and thrombotic or thromboembolic disease: implications for prevention, antithrombotic therapy, and follow-up: JACC state-of-the-art review. J Am Coll Cardiol 75(23):2950-2973

4. Thachil J, Tang N, Gando S et al (2020) ISTH interim guidance on recognition and management of coagulopathy in COVID-19. J Thromb Haemost 18(5):1023-1026

5. Moher D, Liberati A, Tetzlaff J, Altman DG, PRISMA Group (2009) Preferred reporting items for systematic reviews and metaanalyses: the PRISMA statement. PLoS Med 151(4):264-269

6. MetaXL Version 5.3 (2019) https://www.epigear.com/index_files /metaxl.html. Accessed 27 June 2020

7. Llitjos JF, Leclerc M, Chochois C et al (2020) High incidence of venous thromboembolic events in anticoagulated severe COVID19 patients. J Thromb Haemost. https://doi.org/10.1111/jth.14869

8. Helms J, Tacquard C, Severac F et al (2020) High risk of thrombosis in patients with severe SARS-CoV-2 infection: a multicenter prospective cohort study. Intensive Care Med 46(6):1089-1098

9. Fraissé M, Logre E, Pajot O, Mentec H, Plantefève G, Contou D (2020) Thrombotic and hemorrhagic events in critically ill COVID-19 patients: a French monocenter retrospective study. Crit Care 24(1):275

10. Middeldorp S, Coppens M, van Haaps TF et al (2020) Incidence of venous thromboembolism in hospitalized patients with COVID-19. J Thromb Haemost. https://doi.org/10.1111/jth.14888

11. Klok FA, Kruip MJHA, van der Meer NJM et al (2020) Incidence of thrombotic complications in critically ill ICU patients with COVID-19. Thromb Res S0049-3848(20):30120-30121

12. Lodigiani $\mathrm{C}$, Iapichino $\mathrm{G}$, Carenzo L et al (2020 Jul) Venous and arterial thromboembolic complications in COVID-19 patients admitted to an academic hospital in Milan, Italy. Thromb Res 191:9-14

13. Spiezia L, Boscolo A, Poletto F et al (2020) COVID-19-related severe hypercoagulability in patients admitted to intensive care unit for acute respiratory failure. Thromb Haemost. https://doi. org/10.1055/s-0040-1710018

14. Thomas W, Varley J, Johnston A et al (2020) Thrombotic complications of patients admitted to intensive care with COVID-19 at a teaching hospital in the United Kingdom. Thromb Res 191:76-77

15. Desborough MJR, Doyle AJ, Griffiths A, Retter A, Breen KA, Hunt BJ (2020) Image-proven thromboembolism in patients with severe COVID-19 in a tertiary critical care unit in the United Kingdom. Thromb Res 193:1-4

16. Maatman TK, Jalali F, Feizpour C et al (2020) Routine venous thromboembolism prophylaxis may be inadequate in the hypercoagulable state of severe coronavirus disease. Crit Care Med. https ://doi.org/10.1097/CCM.0000000000004466

17. Ren B, Yan F, Deng Z et al (2020) Extremely high incidence of lower extremity deep venous thrombosis in 48 patients with severe 
COVID-19 in Wuhan. Circulation. 2020. https://doi.org/10.1161/ CIRCULATIONAHA.120.047407

18. Zerwes S, Hernandez Cancino F, Liebetrau D et al (2020) Erhöhtes Risiko für tiefe Beinvenenthrombosen bei Intensivpatienten mit CoViD-19-Infektion? - Erste Daten [Increased risk of deep vein thrombosis in intensive care unit patients with CoViD19 infections?-Preliminary data] [published online ahead of print, 2020 Jun 5]. Chirurg. 1-7

19. Varga Z, Flammer AJ, Steiger P et al (2020) Endothelial cell infection and endotheliitis in COVID-19. Lancet S0140-6736(20):30937-30935

20. Begbie M, Notley C, Tinlin S, Sawyer L, Lillicrap D (2000) The Factor VIII acute phase response requires the participation of NFkappaB and C/EBP. Thromb Haemost 84(2):216-222

21. Panigada M, Bottino N, Tagliabue P et al. (2020) Hypercoagulability of COVID-19 patients in Intensive Care Unit. A Report of Thromboelastography Findings and other Parameters of Hemostasis. J Thromb Haemost. doi:10.1111/jth.14850

22. Ranucci M, Ballotta A, Di Dedda U et al (2020) The procoagulant pattern of patients with COVID-19 acute respiratory distress syndrome. J Thromb Haemost. https://doi.org/10.1111/jth.14854

23. Maier CL, Truong AD, Auld SC, Polly DM, Tanksley CL, Duncan A (2020) COVID-19-associated hyperviscosity: a link between inflammation and thrombophilia? Lancet 395(10239):1758-1759

24. PROTECT Investigators for the Canadian Critical Care Trials Group and the Australian and New Zealand Intensive Care Society Clinical Trials Group, Cook D, Meade M et al. Dalteparin versus unfractionated heparin in critically ill patients. N Engl J Med. 2011;364(14):1305-1314

25. Lim W, Meade M, Lauzier F et al (2015) Failure of anticoagulant thromboprophylaxis: risk factors in medical-surgical critically ill patients. Crit Care Med 43(2):401-410

26. Hanify JM, Dupree LH, Johnson DW, Ferreira JA (2017) Failure of chemical thromboprophylaxis in critically ill medical and surgical patients with sepsis. J Crit Care 37:206-210

27. Kaplan D, Casper TC, Elliott CG et al (2015) VTE Incidence and Risk Factors in Patients With Severe Sepsis and Septic Shock. Chest 148(5):1224-1230

28. Priglinger U, Delle Karth G, Geppert A et al (2003) Prophylactic anticoagulation with enoxaparin: Is the subcutaneous route appropriate in the critically ill? Crit Care Med 31(5):1405-1409

29. Rommers MK, Van der Lely N, Egberts TC, van den Bemt PM (2006) Anti-Xa activity after subcutaneous administration of dalteparin in ICU patients with and without subcutaneous oedema: a pilot study. Crit Care 10(3):R93

30. Robinson S, Zincuk A, Strøm T, Larsen TB, Rasmussen B, Toft $P$ (2010) Enoxaparin, effective dosage for intensive care patients: double-blinded, randomised clinical trial. Crit Care 14(2):R41

31. Mayr AJ, Dünser M, Jochberger S et al (2002) Antifactor Xa activity in intensive care patients receiving thromboembolic prophylaxis with standard doses of enoxaparin. Thromb Res 105(3):201-204

32. Dutt T, Simcox D, Downey C et al (2020) Thromboprophylaxis in COVID-19: Anti-FXa-the missing factor? Am J Respir Crit Care Med. https://doi.org/10.1164/rccm.202005-1654LE

33. Karcutskie CA, Dharmaraja A, Patel J et al (2018) Association of anti-Factor Xa-guided dosing of enoxaparin with venous thromboembolism after trauma. JAMA Surg 153(2):144-149

34. Kramme K, Sarraf P, Munene G (2020) Prophylactic enoxaparin adjusted by anti-factor Xa peak levels compared with recommended thromboprophylaxis and rates of clinically evident venous thromboembolism in surgical oncology patients. J Am Coll Surg 230(3):314-321

35. White D, MacDonald S, Bull T et al (2020) Heparin resistance in COVID-19 patients in the intensive care unit. J Thromb Thrombolysis $1-5$

36. Guervil DJ, Rosenberg AF, Winterstein AG, Harris NS, Johns TE, Zumberg MS (2011) Activated partial thromboplastin time versus antifactor $\mathrm{Xa}$ heparin assay in monitoring unfractionated heparin by continuous intravenous infusion. Ann Pharmacother 45(7-8):861-868

37. Beun R, Kusadasi N, Sikma M, Westerink J, Huisman A (2020) Thromboembolic events and apparent heparin resistance in patients infected with SARS-CoV-2. Int J Lab Hematol 42(Suppl 1):19-20

38. Rubulotta F, Soliman-Aboumarie H, Filbey K et al (2020) Technologies to optimize the care of severe COVID-19 patients for healthcare providers challenged by limited resources. Anesth Analg. https://doi.org/10.1213/ANE.0000000000004985

39. Panigada M, Bottino N, Tagliabue P et al (2020) Hypercoagulability of COVID-19 patients in intensive care unit: A report of thromboelastography findings and other parameters of hemostasis. J Thromb Haemost 18(7):1738-1742

40. Mortus JR, Manek SE, Brubaker LS et al (2020) Thromboelastographic results and hypercoagulability syndrome in patients with coronavirus disease 2019 who are critically Ill. JAMA Netw Open 3(6):e2011192

41. Almskog L, Wikman A, Svensson J et al. Rotational Thromboelastometry predicts care level in Covid-19. medRxiv; 2020.06.11.20128710

42. Panigada M, Iapichino E, Brioni G (2018) M, et al. Thromboelastography-based anticoagulation management during extracorporeal membrane oxygenation: a safety and feasibility pilot study. Ann Intensive Care 8(1):7

Publisher's Note Springer Nature remains neutral with regard to jurisdictional claims in published maps and institutional affiliations. 